\title{
Personlige refleksioner over undervisningskvalitet - Ideer til tre aktiverende øvelser
}

\author{
Mette Liv Skovgaard, Undervisningsassistent, Kommunikation, Roskilde Universitet
}

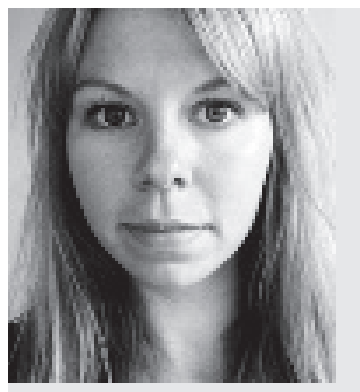

Mette Liv Skovgaard er undervisningsassistent på Kommunikation, Roskilde Universitet. Uddannelsen er karakteriseret ved intensive workshopforløb, hvor de studerende tilegner sig viden om f.eks. skriftlig eller mundtlig formidling gennem praktiske øvelser. Mette har skrevet speciale i kommunikation og historie om museumsformidling til børn, arbejder sideløbende med kulturformidling i Skoletjenesten og har tidligere arbejdet med humanistisk forskning i Kulturministeriet.

Folgende tekst er en kort personlig refleksion over undervisningskvalitet. På baggrund af mine erfaringer fra min undervisning på Roskilde Universitets kommunikationsuddannelse og fra min workshop på DUN konferencen 2009 prosenterer jeg her tre konkrete forslag til deltageraktiverende ovelser, der kan bruges $i$ undervisningssituationer på mindre hold såvel som til store forelasninger. Alle ovelserne sigter mod at oge de studerendes refleksion over egen laring. Ovelserne er i høj grad inspireret af Cooperative Learning (2006), en undervisningsstruktur udviklet af Spencer Kagan og Jette Stenlev. Bogen kan varmt anbefales som inspiration til undervisningsplanlagning $i$ universitetsregi.

\section{Aktivitet som et middel til at skabe kvalitet $i$ undervisning}

"Hvordan skaber vi motiverede studerende?« spørger en deltager i min workshop Kvalitet er konkrete kompetencer på DUNK09. Spørgsmålet er relevant, især set i lyset af konferencens tema om kvalitet i undervisningen. Mit bud er, at ved at skabe rum for de studerendes refleksion og aktive deltagelse i undervisningen sætter vi som undervisere de studerende i centrum. Det giver motivation, energi og lyst til at lære. Både på små hold, i store auditorier - og bestemt ikke kun for kække kommunikationsstuderende, som er den målgruppe, jeg især henter min erfaring fra.

Pointen er, at alle studerende i en læringsoptik har gavn af øvelser og aktivitet $\mathrm{i}$ undervisningen. Når vi aktiveres mundtligt eller bruger hele kroppen i en læringssituation, skabes der rammer for, at vi kan tænke friere og forstå stoffet bedre. Som workshopholder konkretiserede jeg denne pointe i en række øvelser, de 35 workshopdeltagere på DUNK09 velvilligt kastede sig ud i. Som i en mægtig myreture eller mellemøstlig basar var både temperaturen og stemningen i lokalet høj. Efter workshoppen henvendte mange sig og efterspurgte opskrifter på, hvordan øvelserne, de lige havde prøvet, kunne implementeres i egen undervisning. Derfor denne artikel, der præsenterer og argumenter for tre af øvelserne.

\section{Prøv en øvelse - det er din øvelse}

Indledningsvis vil jeg gerne slå fast, at skepsis og usikkerhed omkring nye undervisningspraksisser er forventelige og forståelige. Men et argument a la "noget stof er bare tørt og kan kun gennemgås traditionelt« er reaktionær. Både i relation til den aktuelle debat om kvalitet $\mathrm{i}$ universitetsundervisningen og konkret i forhold til universitetets vigtigste målgruppe, de studerende.

En start kan være at afprøve en enkelt øvelse i egen undervisningsregi, hvad enten det er i biokemi, grammatik eller Bourdieu for begyndere, og se, om ikke det virker. Dermed er bolden givet op til at implementere mere aktivitet - og kvalitet - i undervisningen. Følgende tre øvelser har alle det til fælles, at de sigter mod at styrke deltagernes bearbejdning af undervisningsstoffet og deres refleksion over egen læring. Øvelserne er variationer over samme tema.

\section{Øvelse 1: Individuel refleksion: Hvad tager den studerende med sig?}

Et vigtigt element $i$ god undervisning er at gøre det klart for de studerende, hvilke kompetencer og hvilken viden de tager med sig hjem. Det har en motiverende effekt på dem, når de kender undervisningens mål, og når underviseren giver rum for refleksion over dagens forelæste emne. 
Ved at skabe plads til refleksionen kan du som underviser give de studerende mulighed for at overveje, hvad de har hørt til forelæsningen, og hvordan de kan bruge det. Afslut dagens undervisning med 3 minutter, hvor de studerende individuelt skriver ned, hvad de oplevede som dagens hovedpointe, som de vil tage med sig. Giv grundige instrukser om, at det er en øvelse for deres skyld: De kan for eksempel skrive hvad de finder vigtigst, er blevet klogere på, blev mest overraskede over eller synes de kan bruge i praksis. Pointen er personlig, og de studerende skal ikke dele den med andre eller læse den op i plenum efterfølgende.

\section{Øvelse 2: Dobbeltcirklen: Erkendelse og læring gennem verbalisering}

Aktiv deltagelse $\mathrm{i}$ undervisningen kan bruges til at skabe grobund for refleksion over det stof, de studerende præsenteres for og dermed andre former for læring end traditionelt formidlende undervisningsformer. Tænk for eksempel over, hvor forskellig energi det giver dig, hvis du underviser henholdsvis siddende eller stående, stille eller i bevægelse. Øvelsen er hentet fra Cooperative Learning.

Bed de studerende stille sig over for hinanden to og to i en dobbeltcirkel. (En dobbeltcirkel er to cirkler, hvor den ene cirkel er inde i den anden). Stil en opgave eller et spørgsmål, hvor de studerende henholdsvis skal skiftes til at svare eller lytte til hinanden. Efter et minut bytter de, du tager tid og giver signal. Når begge har talt, rykker den yderste cirkel et skridt til højre og får en ny partner. De taler igen om det samme og får på hermeneutisk vis talt sig frem til en dybere eller ny erkendelse heraf.
Øvelsen kan bruges løbende i forelæsningen på holdet eller som opsamling på dagens undervisning. Spørgsmål du beder eleverne tale om, kan være »Hvad ser du som hovedpointen i teksten til i dag« eller »Hvad har overrasket dig/givet dig ny viden i dag«. I workshoppen på DUNK09 var spørgsmålet "Hvad ser du som kvalitet i undervisningen?«

\section{Øvelse 3: Spørgetur: Opklarende, reflekterende og aktiverende}

Øvelsen er formmæssig lidt anderledes end dobbeltcirklen, men giver på samme måde de studerende mulighed for at reflektere over undervisningen og selv komme til orde. Den er ligeledes hentet fra Cooperative Learning.

De studerende starter med at skrive et spørgsmål til undervisningen på en seddel. Bagefter træeder de ud på gulvet i flok, går rundt mellem hinanden og finder en partner, som de læser deres spørgsmål højt for og den anden svarer på. De har hver 1-2 minutter til at svare, hvorefter de bytter og den forste svarer på den andens spørgsmål. Når de begge har svaret på hinandens spørgsmål, bytter de sedler og går videre til en ny partner. Her stiller de det spørgsmål, der står på den seddel, de har fäet, og som de selv lige har svaret på - på den måde får de måske et nyt svar med en anden vinkel.

God fornøjelse!

\section{Litteratur}

Kagan, S. og Stenlev J. (2006). Cooperative Learning. Danmark: Alinea 